DOI: 10.20472/BMC.2018.008.010

\title{
JURAJ MISUN
}

University of Economics in Bratislava, Slovak Republic

IVANA MISUNOVA HUDAKOVA

University of Economics in Bratislava, Slovak Republic

\section{NEW TRENDS IN CONTROL(-LING): QUALITATIVE ANALYSIS OF RESULTS}

\begin{abstract}
:
Internal controlling represents all control activities, which are performed within a certain system. In addition to this approach, there is also an approach relates to the motivation of the individual and the popular practical financial approach, designed to provide reasonable assurance regarding the achievement of objectives. Since three meanings of one term may be counterproductive, we will recommend a slight change. Controlling might be influenced by accounting, social control and cybernetics, yet it is still the least researched function of management. During the expansion of the economy, this function of management can hide, but it is very well prepared to intervene if the economic cycle turns into a recession or any kind of crisis appears on the horizon. In Europe, control was associated with investigation, accusation and subsequent punishment and therefore it has negative associations. This paper does not use the term controlling in the German meaning that understands it as a subsystem of management and considers the participation of a controller as a key factor.

Based on a questionnaire survey from the turn of 2016 and 2017 we are determining new trends in internal controlling. In addition to quantitative responses, we have analyzed in previous papers, we conclude this research with the analysis of qualitative responses. As these data offer a deeper insight into the issues of individual questions, the aim of this paper is to evaluate them. Additionally, in various parts of the paper, we indicate new knowledge about the management function of controlling.
\end{abstract}

\section{Keywords:}

Controlling, management function, management accounting, internal control, new trends

JEL Classification: M10, M19 


\section{Introduction}

Internal controlling represents (in the Eastern approach to control) all control activities that are performed within a certain (mostly economic) system. In addition, in the Western approach it relates to the motivation of the individual to perform the work conscientiously without the need for control by someone else and in the popular practical financial approach it is a process designed to provide reasonable assurance regarding the achievement of objectives. Since three meanings of one term may be counterproductive, we recommend a slight change.

Although controlling is clearly the least researched function of management, despite the fact that it is influenced by accounting, social control and cybernetics, its development is shifting forward. During the expansion of the economy, control can hide, but it is very well prepared to intervene if the economic cycle turns into a recession or any kind of crisis appears on the horizon.

Unfortunately, controlling has many negative associations in the human mind and, in particular, in Europe, it is associated with investigation, accusation and subsequent punishment of the controlled subject.

While control is a one-time act, controlling is a constantly ongoing managerial process of designing standards, measuring performance, comparing the performance with standards, and implementing corrective actions to ensure effective and efficient running of the organization's activities.

This paper does not use the term controlling in the German meaning, as many, particularly Central and Eastern European authors in the area of business economics, do not sufficiently distinguish between the English and German meaning of this term. In business economics we often find inaccurate resolutions of terms control and controlling, where the first one is figuratively described as a villain and the other one as a hero. ${ }^{1}$

At the turn of 2016 and 2017, a questionnaire survey was carried out within the framework of the newly approved research project on trends in internal controlling. Out of 395 received, 376 questionnaires from 331 different companies operating in the Slovak Republic were further processed. In addition to quantitative responses in the form of choice or scale, we also asked the respondents for a short justification of their choice. These qualitative responses served on the one hand to eliminate potential incompetent respondents, but at the same time provided a great amount of extra data. As these data offer a deeper insight into the issues of individual questions, the aim of this paper is to evaluate them.

\footnotetext{
${ }^{1}$ For more information, please read our second submission to this conference entitled "Two Controlling Terms: Half a Century of Coexistence".
} 


\section{Theoretical background}

In this paper, we describe controlling as a management function, distinguish Western and Eastern approaches to controlling, and specify three meanings of internal control.

\subsection{Controlling, the management function of control}

"Controlling" is used as a chapter title perhaps in every English-written management textbook to describe the management function of control. Additionally, planning, organizing, staffing and leadership functions are performed (mostly) before controlling.

Also due to its status as the last step of the management process, it is the least researched function. Based on the study of literature, much more attention is paid to the other sequential functions. From parallel managerial functions, the decision-making function enjoys also more attention.

Fayol brought one of the first definitions of managerial function of control in 1949, when he stated: "control of an undertaking consists of seeing that everything is being carried out in accordance with the plan which has been adopted, the orders which have been given, and the principles which have been laid down. Its object is to point out mistakes in order that they may be rectified and prevented from recurring." Anthony later defined control as the process through which managers ensure that resources are procured and used efficiently and effectively to meet the goals of the organization. Among the Slovak authors, Kráčmar et al. (2013) define control as a specific, multi-step activity, which provides information for correcting plans and supporting decision makers through the control process.

The controlling function of management can be a critical determinant of organizational success. (Merchant, 1982) Failures in control can lead to large financial losses, damage to reputation, and even to the failure of the entire organization. (Merchant \& Van Der Stede, 2007) Its importance derives from its versatility as well as from many implications of how organizations behave. (Tannenbaum, 1965) Through control, companies try to increase the probability that individuals and groups will behave in a way that will lead to organizational goals. This means that control is purposeful and its purpose is to influence people to take action and make decisions that are in line with the organization's goals. (Flamholtz et al., 1985) Control is an incentive for the subject of management to ensure dynamic balance by new decisions. (Konečný, 1998) In order for the control process to be meaningful, organizations need to be aware of and have the ability to adjust the situations they identified as out-of-control. Otherwise, control does not serve any purpose. (Atkinson et al., 2012) It is important to recognize that the control function of management is present in all processes running in the company. If its techniques and procedures change, it never changes its substance, that is, how to use resources appropriately and efficiently to achieve planned outputs and to get closer to achieve the 
strategic goals of the company. (Petrík, 2005) According to Merchant, Van der Stede and Zheng (2003) control represents the ending of the management process.

It should be clear that with its primary characteristics, which are feedback and corrective action, controlling is a fundamental and integral part of the role of management. Without controlling, there can be no management. (Eilon, 1971)

Very important concepts of control are the efficiency and effectiveness through which managers are trying to achieve their goals. Effectiveness is interested in achieving the goals; that is, the action is expedient to the extent to which what was intended was achieved. Efficiency is interested in achieving the result with minimal use of resources. (Emmanuel et al., 1990)

Unfortunately, in Europe, research has not had to rely on English-language knowledge for a long time, and thus the parallel use of the term has arisen. In German speaking countries the term controlling has been used since the 1970s. It describes a subsystem of management, which includes in addition to the manager's work also the controller's work.

\subsection{Western and Eastern approach to control}

Although the current management theory may appear to be globally identical, there are large differences in the control function. During our research, we have discovered several diametrical differences between Western theory of control and the theory that gradually developed in the Soviet bloc countries. We call this theory the Eastern approach to control. However, the common feature is not geographic location, but similar history. While China is part of Eastern approach, India and Japan are not. Nearly all of the studied works from the last two mentioned countries have a clear connection to British and American literature.

We believe that these differences are due to the genetics of dictatorial regimes. Strict formal control brings high discipline. We use the word "genetics" intentionally, as we observe not only the "I have to control someone" opinion but also the "I want to be controlled by someone" approach in our surveys. We point out the major differences between the Western and Eastern approach to control in table 1, while the sophisticated classification of formal control is shown in table 1. On the other hand, there is the Western approach that puts emphasis on self-control and self-discipline with the opinion "in order to make a good job, I have to control my work by myself". 
Tab. 1: Different aspects of the Western and Eastern approach to controlling

\begin{tabular}{|c|c|c|}
\hline Aspect & Western approach & Eastern approach \\
\hline Types of control & $\begin{array}{l}\text { mainly feedforward, } \\
\text { concurrent, and feedback } \\
\text { controls }\end{array}$ & $\begin{array}{l}\text { sophisticated typology with the accent } \\
\text { on formal control }\end{array}$ \\
\hline Forms of control & $\begin{array}{l}\text { bureaucratic/administrative, } \\
\text { clan, and market control }\end{array}$ & $\begin{array}{l}\text { verification, control survey, supervision, } \\
\text { inspection, review, audit, operational } \\
\text { research }\end{array}$ \\
\hline $\begin{array}{l}\text { Steps in control } \\
\text { process }\end{array}$ & mainly three to four & five to eight \\
\hline $\begin{array}{l}\text { Meaning of } \\
\text { external control }\end{array}$ & $\begin{array}{l}\text { a manager controls an } \\
\text { employee }\end{array}$ & $\begin{array}{l}\text { an entity outside the organization } \\
\text { controls its operations, results or state }\end{array}$ \\
\hline $\begin{array}{l}\text { Meaning of } \\
\text { internal control }\end{array}$ & $\begin{array}{l}\text { an employee or a manager } \\
\text { controls himself or herself }\end{array}$ & a manager controls an employee \\
\hline Level of control & $\begin{array}{l}\text { strategic, management, } \\
\text { operational }\end{array}$ & deficiently covered in literature \\
\hline Object of control & results, actions or personnel & $\begin{array}{l}\text { systems that may be target-influenced } \\
\text { (social systems and man, technical } \\
\text { systems, biological and inanimate } \\
\text { systems) }\end{array}$ \\
\hline Subject of control & $\begin{array}{l}\text { what is being controlled } \\
\text { (similarly to object of control } \\
\text { in the Eastern approach) }\end{array}$ & $\begin{array}{l}\text { an entity who has organizational or } \\
\text { legal power to exercise control over an } \\
\text { object of control }\end{array}$ \\
\hline
\end{tabular}

Source: own work based on a large number of Western and Eastern literature

\subsection{Three meanings of internal control}

There is another important aspect in controlling that we have mention - three different meanings of the term internal control.

First, there is the Western approach. It places emphasis on the individual, whether he or she is sufficiently motivated. Does the individual need to be heavily controlled by anyone else (external control), or can he/she perform sufficient supervision on his/her own work and results (internal control). "Since Rotter (1954) first introduced his theory of social learning, there has developed an extensive body of research surrounding the central construct of locus of control." While the perceived internal locus of control believes one's personal belief has influence over outcomes through his skills, abilities, and efforts; the external locus of control believes that external forces can control outcomes. (Kaufmann et al., 1995)

Secondly, there is the popular practical financial meaning of the Committee of Sponsoring Organization (COSO) with its great emphasis on finance, risk, and so on. "Internal control is a process, effected by an entity's board of directors, management, and other 
personnel, designed to provide reasonable assurance regarding the achievement of objectives relating to operations, reporting, and compliance." (Committee of Sponsoring Organizations, 2013)

Last but not least, the Eastern approach. The difference between internal and external controlling lies in whether the object and subject of control are part of one system or not. "Control can be classified as external control and internal control from the perspective of control subject." (Zhang, 2014, p. 45) External control means that the controllers are from the outer environment of the organization (subject and object come from different organizations). Examples include controls from government sector, financial control, taxation control, government audit control etc.

Because of the three different meanings of the concept of internal control, it would be appropriate to rename the Eastern approach to inner control. If the subject and object did not come from the same system, the term would be outer control.

\section{Methodology}

Our presented research results are coming from a questionnaire survey, which collected data at the turn of 2016 and 2017. Questionnaire's emphasis was on new trends in controlling in management and its results should serve the needs of our research project.

We received 395 completed questionnaires, 376 were further processed and 19 excluded. Although the research sample is not statistically representative, it is compatible with the parameters of the Slovak Republic.

In the case of the first two questions concerning the respondent's attitude to control, there could have been several respondents from the same business. However, this paper does not cover these questions and therefore further selection is needed. In the case of more respondents, only the highest ranked in company's hierarchy was left in research. Accordingly, our sample contains 331 enterprises, with the following characteristics $(n=$ 331):

- size of company (employees in 2015): 115 microenterprises, 90 small, 56 mediumlarge, 70 large companies;

- management level of the respondent: 120 top-management, 52 middle, 116 lower management level, 43 informed employees (Although they do not hold a managerial position, "informed employees" represent an important part of our research sample as they have access to rare business information. Included are accounting officers, economists and employees directly responsible for the control function (without being managers).)

- most frequently represented sections according to the SK-NACE classification: 69 industrial production, 66 wholesale and retail trade and repair of motor vehicles 
and motorcycles, 46 professional scientific and technical activities, 25 information and communication, 21 accommodation and catering services;

- higher territorial unit of Slovak Republic: 174 Bratislava (capital city and surrounding districts), 33 Trnava, 24 Nitra, 23 Trenčín, 30 Žilina, 17 Banská Bystrica, 22 Prešov, 8 Košice;

- legal form: 222 private limited liability companies, 66 joint-stock companies, 30 self-employed individuals, 5 branches of an foreign enterprise, 4 cooperatives, 4 other legal forms;

- economic result in 2015: 254 profit, 52 loss, 20 balanced economic result, 3 companies founded in 2016, 2 n/a;

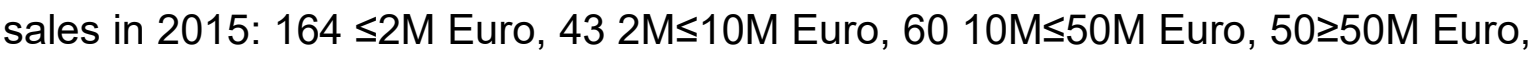
$14 \mathrm{n} / \mathrm{a}$.

What is important for our paper is that, in addition to the quantitative answers, the questionnaire also contained the opportunity to express opinions through short justifications. Thanks to this and the willingness of our respondents, we collected a relatively large amount of data for processing with a relatively short questionnaire. The justifications were also very helpful for a deeper insight into the particular issues and for the exclusion of incompetent respondents.

The obtained qualitative data in individual questions was categorized according to their content proximity and subsequently evaluated. We used standard scientific methods in evaluating and interpreting the results of our questionnaire surveys.

\section{Discussion}

In this part of the paper, we will analyze the qualitative results of the individual questions while maintaining the structure of the questionnaire. As we mentioned above, the first two questions about the respondent's attitude to control, will not be described in this paper. This is due to the excessive volume of data in their responses and a partially different research sample. We will highlight a few facts from quantitative analysis of the remaining questions and categorize the qualitative responses.

In the following table (2), we will show a number of examples of justifications given by our respondents for individual questions. 
Tab. 2: Examples of justifications of respondents to questions

\begin{tabular}{|c|c|c|c|}
\hline Question & Answer & Justification & $\begin{array}{l}\text { Respondent } \\
\text { description }\end{array}$ \\
\hline $\begin{array}{l}\text { Importance } \\
\text { of control }\end{array}$ & $\begin{array}{l}\text { very } \\
\text { important }\end{array}$ & $\begin{array}{l}\text { Without control everyone is doing what he } \\
\text { t wants, workers need to be aware that they are } \\
\text { constantly controlled. This increases their } \\
\text { performance. }\end{array}$ & $\begin{array}{l}\text { Service manager } \\
\text { of a large } \\
\text { wholesale } \\
\text { company }\end{array}$ \\
\hline $\begin{array}{l}\text { Importance } \\
\text { of control }\end{array}$ & important & $\begin{array}{l}\text { Control is of particular importance to us in the } \\
\text { entry and exit of production, the production } \\
\text { process and the management of employees is } \\
\text { less important due to self-control. }\end{array}$ & $\begin{array}{l}\text { Owner of a small } \\
\text { installation } \\
\text { company }\end{array}$ \\
\hline $\begin{array}{l}\text { Changes } \\
\text { in } \\
\text { controlling }\end{array}$ & yes & $\begin{array}{l}\text { Lately we are particularly interested in } \\
\text { protecting our data, the company's internal } \\
\text { affairs. Controls are mainly interested with IT, } \\
\text { access to our servers, databases, etc. }\end{array}$ & $\begin{array}{l}\text { manager, retail } \\
\text { micro-enterprise }\end{array}$ \\
\hline \begin{tabular}{l|} 
Changes \\
in \\
controlling
\end{tabular} & no & $\begin{array}{l}\text { We have not made any changes in the last year } \\
\text { regarding the way of controlling. It was not } \\
\text { necessary, due the control system was } \\
\text { gradually evolving since our founding. It is now } \\
\text { working well for our needs. }\end{array}$ & $\begin{array}{l}\text { owner, small } \\
\text { wholesale } \\
\text { company }\end{array}$ \\
\hline $\begin{array}{l}\text { New tools, } \\
\text { methods, } \\
\text { procedures } \\
\text { in } \\
\text { controlling }\end{array}$ & yes & $\begin{array}{l}\text { There is a strategy in the Bratislava branch of } \\
\text { our company for becoming a Center of } \\
\text { Excellence. In other words, it is an effort to } \\
\text { deliver services not only at the required level } \\
\text { but to go beyond what is required. The next } \\
\text { step is to attract services with higher added } \\
\text { value, and later define the global processes that } \\
\text { would govern our branches worldwide. } \\
\text { Therefore, the individual departments need to } \\
\text { assess their situation where they are likely to be } \\
\text { on this road and make plans to move forward. } \\
\text { At regular intervals, their position is evaluated. }\end{array}$ & $\begin{array}{l}\text { head of } \\
\text { department, large } \\
\text { advisory company }\end{array}$ \\
\hline $\begin{array}{l}\text { New tools, } \\
\text { methods, } \\
\text { procedures } \\
\text { in } \\
\text { controlling } \\
\end{array}$ & no & $\begin{array}{l}\text { A new control method was introduced some 3-4 } \\
\text { years ago to ensure workers' safety by } \\
\text { checking that workers control and comply with } \\
\text { all rules related to their safety and plant safety. }\end{array}$ & $\begin{array}{l}\text { group manager, } \\
\text { large energy } \\
\text { producer }\end{array}$ \\
\hline $\begin{array}{l}\text { Increasing } \\
\text { control as } \\
\text { subject }\end{array}$ & yes & $\begin{array}{l}\text { With the arrival of new employees into } \\
\text { production, efforts have been stepped up to } \\
\text { motivate them to work. }\end{array}$ & $\begin{array}{l}\text { production } \\
\text { manager, medium- } \\
\text { large chemical } \\
\text { company }\end{array}$ \\
\hline $\begin{array}{l}\text { Increasing } \\
\text { control as } \\
\text { subject }\end{array}$ & no & $\begin{array}{l}\text { Employee turnover is minimal, one could say, } \\
\text { none. The company has been working with the } \\
\text { same people since establishment, who know } \\
\text { the control system well. Self-control in the } \\
\text { company works very well. There is no need to }\end{array}$ & $\begin{array}{l}\text { owner, small } \\
\text { wholesale } \\
\text { company }\end{array}$ \\
\hline
\end{tabular}




\begin{tabular}{|l|l|l|l|}
\hline & increase the intensity. & \\
\hline $\begin{array}{l}\text { Increased } \\
\text { control as } \\
\text { object }\end{array}$ & yes & $\begin{array}{l}\text { In 2016, we had two internal controls and } \\
\text { several external controls. We experience } \\
\text { increased control intensity over the last period. }\end{array}$ & $\begin{array}{l}\text { project manager of } \\
\text { a small research } \\
\text { company }\end{array}$ \\
\hline $\begin{array}{l}\text { Increased } \\
\text { control as } \\
\text { object }\end{array}$ & no & $\begin{array}{l}\text { I did not feel increased control. The fact is that } \\
\text { external inspections from state institutions are } \\
\text { running normally and more or less smoothly. }\end{array}$ & $\begin{array}{l}\text { Channel marketing } \\
\text { manager, small } \\
\text { wholesale } \\
\text { company }\end{array}$ \\
\hline
\end{tabular}

Source: own research results

\subsection{Importance of the management function of control in the company}

The third question in our questionnaire asked about the perceived importance of the management function of controlling in the company in which the respondent operates. To answer this question, respondents had a range available: totally unimportant, not very important, present, important, very important.

Despite the fact that the data collection was carried out during the economic growth phase, the quantitative results on this issue show that controlling does not lose importance. In 142 companies (42,9\%), controlling was perceived to be "very important", in 133 business units $(40,18 \%)$ respondents perceived controlling as "important". In 43 companies $(12,99 \%)$ was controlling perceived as "present", in $12(3,63 \%)$ as "not very important" and only one respondent stated that controlling is in his company "totally unimportant". However, his justification was as follow: "We are a small family business, so we do not have such a position at all and we consider it as unnecessary. All problems and errors in production are solved by the Director and myself as Deputy Director." However, using qualitative analysis, we can say that the respondent justifies his choice mainly by the size of the business. In the next sentences, he admits that the director, as well as himself - his deputy, are paying enough attention to controlling to ensure satisfying results. In addition, it is clear that neither of them is relying on output control. They use concurrent control that ensures loss reduction, as the process is monitored, not just the result.

Our results also show that the larger the enterprise, the higher is the perceived importance of the management control function. In addition, the higher the manager is situated in company's organizational structure (hierarchy), the more important controlling is considered. An exception to this rule is micro-entrepreneurs.

Interestingly, many respondents believe that controlling may be very important only if there is a separate job position of the controller. This could indicate the concept of German controlling, which has expanded strongly lately. The role of a controller is to provide information based on financial and managerial accounting, which can help managers to decide better. Unfortunately, such opinions may result to a so-called 
professional understanding of controlling. This, in turn, causes that managers inadequately exercise their control functions, as they may assume that another body has to control. In addition, controllers process very well quantitative data. Due to the nature of their work, they mostly do not receive qualitative data at all. A missing combination of these two kinds of data may result in an incorrect manager's decision.

Of the 331 enterprises surveyed, 314 respondents provided us with a justification of the perceived importance of controlling. Only 17 respondents did not justify the perceived importance. Since quantitative responses "very important" and "important" represent up to four-fifths of all responses to the question, we will only consider these two answers when analyzing qualitative justifications. This means we will analyze 275 justifications.

We have divided these justifications into nine categories, including the "no justification" category, which had 20 responses.

We have assigned the most justification to the "compliance and/or improvement of processes" category. It includes 58 justifications where companies control individual processes and try to contribute to improving processes through controlling.

The second largest category was with 56 justifications "general reasons". These justifications mostly highlighted the general need for controlling for a successful business, customer satisfaction, order, feedback, and so on.

The third most represented category (with 31 justifications) concerned the quality and improvement of products or services.

Relatively the same number of justifications was given in the categories "meeting objectives, strategies" (24), "efficiency of employees" (23) and "avoiding mistakes and negative impacts" (21), which do not require a more detailed explanation.

The last separate category is the "compliance with processes to meet the goals" with 15 responses. It means that companies try to perform controls on individual processes in order to achieve the goals.

To the category "other" we included the justifications that referred to the information nature of the control (14), legislative reasons of controls (10), or that controlling is important for decision making (3). The percentage of individual categories is shown in Figure 1. 


\section{Figure 1: Shares of categories in importance of management function control}

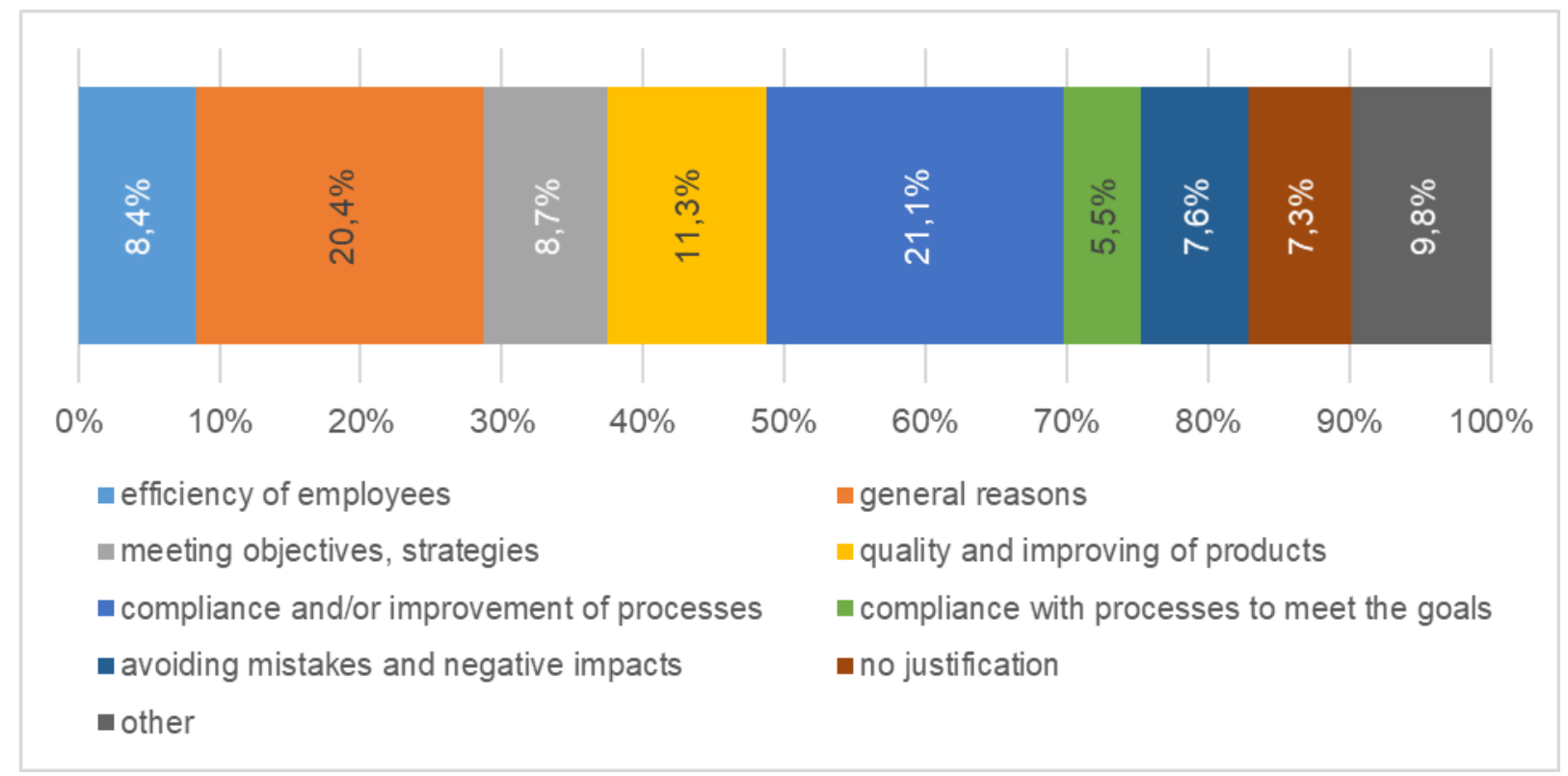

Source: own research results

\subsection{Control-related changes in the company}

The fourth question of the questionnaire approached the topic of our research project, in the form of asking for changes in the field of controlling. Besides, it is an important fundament for two dissertations.

Up to 157 respondents of the 331 surveyed companies in our sample stated, they had seen changes in the area in the year before completing the questionnaire. The larger part, 174 respondents, said that their company did not make any major changes in controlling or they did not notice one. In the group of the positive answer, 153 respondents have justified their choice and, in the group of negative answers, 75 respondents.

Several interesting facts emerged as part of the quantitative assessment: a) profitable businesses have made changes rather than those that have recorded a loss in 2015; b) if controlling was considered "very important," the company more likely implemented changes in this area.

We will qualitative analyze only the positive answers, including the category "no justification" with only 4 respondents. In the justification, we asked our respondents: "In a few words, please clarify the changes you noticed."

The largest category, consisting of 63 justifications, is "outer control from state". It includes statements, which point out the increasing intensity of control coming from institutions of the public administration. The justifications often related to tax inspections, 
tightened conditions based on legislation, employment control, or compliance with environmental protection requirements.

The second most common category of justifications was "internal changes in company". In this category, we have included changes in the organization that have increased the need for control, for example controls of performance, workers, or goods. We can assign 51 justifications to this category.

The third most common reason for making changes in controlling - with 17 justification was the introduction of new information technologies, computerization or automation in the area. We called this category "control by new IT and computerization".

We have assigned 13 justifications to the "external impact (customer's requirements)" category. This was primarily the external impact on the organization from the point of view of the customer and his requirements (emphasis on increasing quality, prices, specific customer requirements).

The smallest category has nine responses and the name "new business processes". In addition to the introduction of new processes in the company, the justifications also revealed slimming the processes or adaptation to the global network. The share of individual categories is shown in Figure 2.

\section{Figure 2: Share of categories in changes in controlling in the company}

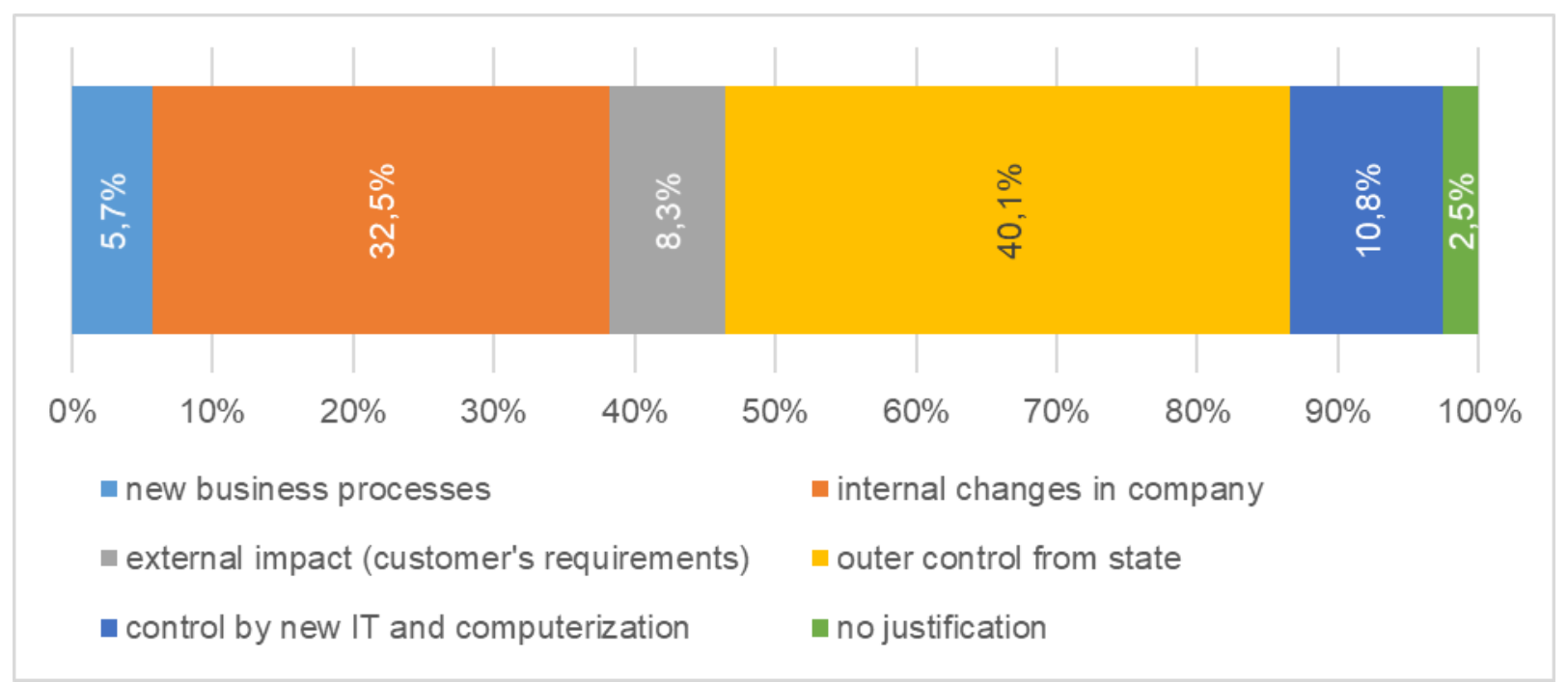

Source: own research results

\subsection{New tools/methods/procedures in controlling}

In view of the focus of our research project, the probably most important question was the one that asked, "Has your company introduced a new tool/new method/new procedure in your company last year that would be of fundamental concern for controlling in management?" In the case of a positive response, we asked the respondents for a brief justification. 
The share of positive responses to this question reached 120, with up to 119 respondents stating a justification. Members from 210 enterprises declared a negative answer and one respondent did not answer the question with the following reason: "I'm in the company for a short while, so I cannot judge this."

In the quantitative results, we discovered an increasing likelihood of introducing new tools, methods and procedures in controlling with the increasing business size. We think this very much related to the complexity of the business. While in the case of small businesses the work and the processes are quite transparent, in medium-sized and large enterprises, managers increasingly have to rely on indirect control through certain media or with the help of controller. This creates a fertile ground for the emergence of something new in controlling.

Another interesting finding from quantitative data was that the lower lover the manager is situated at the hierarchy in company, the sooner he is responding to the introduction of something new in controlling positive. We assume, this related to the fact that top management often decides on control tools, methods and procedures, but uses them to a lesser extent. Conversely, the use rises with lower levels of management.

In the quantitative answers of our respondents, we also recognized a great connectivity between the perceived importance of controlling in the company and the introduction of new tools, methods and procedures in this area. Simply put, in such a way top management could communicate the fact that controlling belongs to its priorities and wishes to have a high degree of order in the business.

As for the qualitative answers in the form of the justifications, we have encountered a problem of less mutual compatibility of responses. Due to this fact, we had to create up to twelve different categories, with the size of many categories being very similar. Given the high number of categories in the justifications, the number of individual responses is shown in Table 3.

\section{Tab. 3: Categories of qualitative responses in new tools/methods/procedures in controlling}

\begin{tabular}{|l|l|r|}
\hline \multicolumn{1}{|c|}{ Category } & \multicolumn{1}{|c|}{ Description } & Resp. \\
\hline $\begin{array}{l}\text { Innovation or } \\
\text { introduction of } \\
\text { new control } \\
\text { procedures }\end{array}$ & $\begin{array}{l}\text { Introducing completely new control processes or upgrading } \\
\text { control processes already in use. Some responses also } \\
\text { resulted in continuous improvement of processes - not just a } \\
\text { one-time operation. }\end{array}$ & \\
\hline $\begin{array}{l}\text { Accounting, } \\
\text { management }\end{array}$ & $\begin{array}{l}\text { Systems and processes related to management accounting } \\
\text { (German controlling), accounting and other financial }\end{array}$ & \\
\hline $\begin{array}{l}\text { New software to } \\
\text { help control }\end{array}$ & $\begin{array}{l}\text { Implementation of software to help control, perform various } \\
\text { business activities, improve quality of work, automation } \\
\text { overall, etc. }\end{array}$ & 16 \\
\hline
\end{tabular}




\begin{tabular}{|l|l|r|}
\hline $\begin{array}{l}\text { Control of } \\
\text { employees }\end{array}$ & $\begin{array}{l}\text { Processes related to any control of employees - whether } \\
\text { attendance, performance, etc. }\end{array}$ & 13 \\
\hline $\begin{array}{l}\text { Delegation, } \\
\text { manager }\end{array}$ & $\begin{array}{l}\text { The emergence of new managerial positions what is closely } \\
\text { related to delegation. In some replies, delegation to lower } \\
\text { levels of management (or even staff) was also stated. }\end{array}$ & 12 \\
\hline CRM, marketing & $\begin{array}{l}\text { The CRM category includes answers that mainly concerned } \\
\text { customer relationships; category does not include quality } \\
\text { control that is closely related to meeting customer needs. }\end{array}$ & 11 \\
\hline $\begin{array}{l}\text { Regular } \\
\text { controlling }\end{array}$ & $\begin{array}{l}\text { The time aspect of controlling was highlighted in the } \\
\text { responses. Either as a more regular control or as a change of } \\
\text { output control for preliminary and concurent control. }\end{array}$ & 9 \\
\hline ISO, SOP & $\begin{array}{l}\text { Processes relating to the use of ISO standards and guidelines } \\
\text { (SOP - standard operating procedures or general regulations, } \\
\text { procedures, etc.). }\end{array}$ & 8 \\
\hline Quality control & $\begin{array}{l}\text { Responses are essentially concerned with adhering to and } \\
\text { improving quality standards. }\end{array}$ & 5 \\
\hline KPI & Performance indicators (key performance indicators). & 4 \\
\hline $\begin{array}{l}\text { Comprehensive } \\
\text { business } \\
\text { process control } \\
\text { system }\end{array}$ & $\begin{array}{l}\text { Establish a comprehensive business process control system } \\
\text { not only in the area of quality management, but also in the } \\
\text { environment or health protection at work. }\end{array}$ & 2 \\
\hline Feedback & $\begin{array}{l}\text { Increasing and improving feedback inside the organization } \\
\text { between management and employees, possibly with each } \\
\text { other, including mutual control. }\end{array}$ & \\
\hline
\end{tabular}

Source: own research results

The share of individual categories is shown in Figure 3. The categories with the least amount of responses (quality control, KPI, comprehensive business process control system, feedback) are part of the "other" category. 
Figure 3: Share of categories in new tools/methods/procedures in controlling

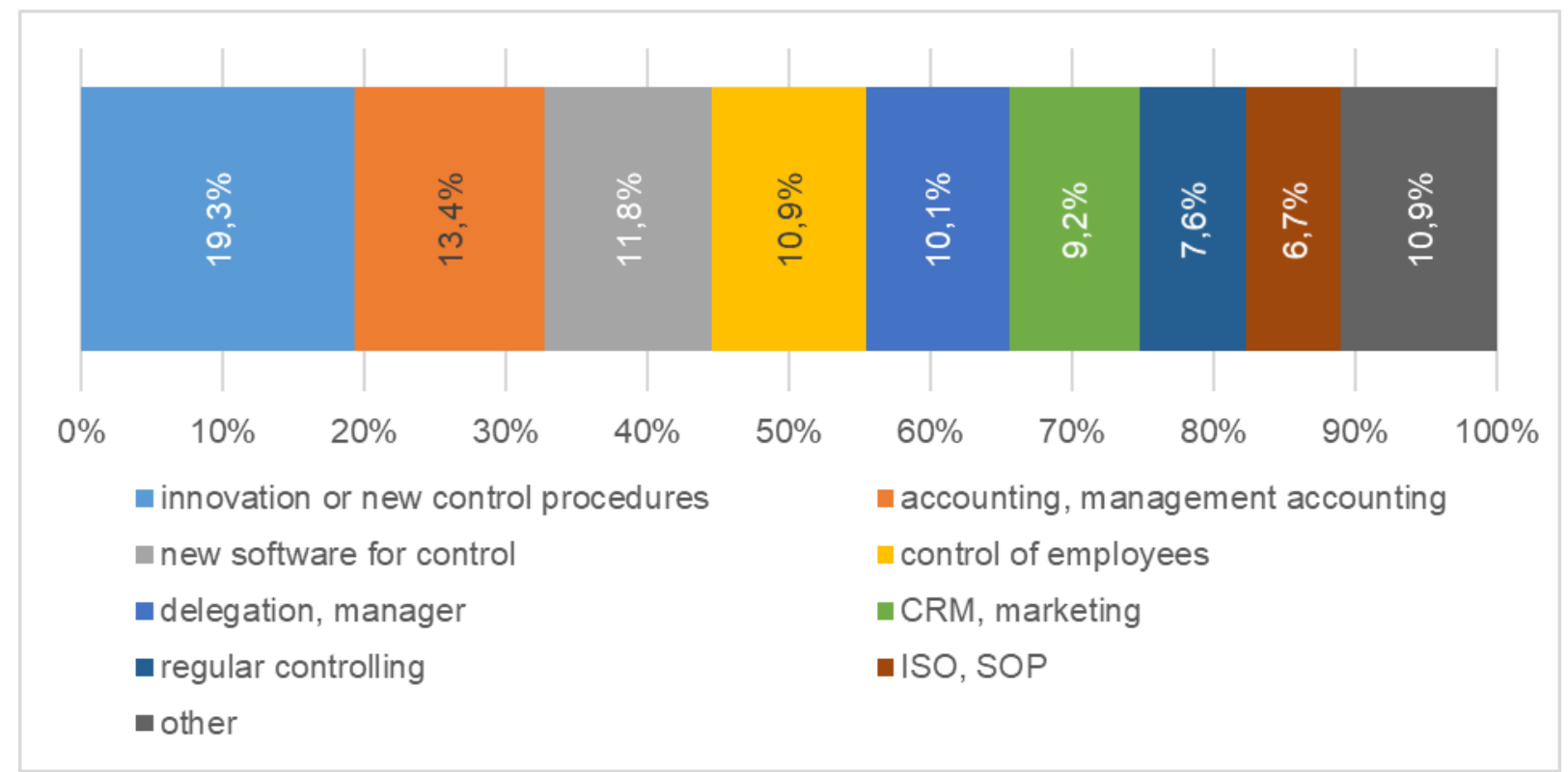

Source: own research results

As we mentioned above, we asked respondents that if their business introduced a new tool $/ \mathrm{method} /$ procedure, to specify what exactly changed. However, the respondents with a negative response pleasantly surprised us, because in 103 cases they explained why nothing new in controlling was introduced. This gives us a solid foundation for qualitative analysis.

Of the total of 210 negative responses, 130 respondents did not provide a justification or a more detailed specification why there was no change in controlling. The second largest category, with 55 replies, contained responses that indicated satisfaction with the current state of controlling in the business. Managers do not see the need to change the status. In the "other" group, we have grouped small categories (changes were implemented sooner, no change was in the control of the respondent, no institutionalized instruments or interest in them), with a total of ten responses. Worth mentioning are also small categories like "change unnecessary due to company's size/age" with six justifications, slow "changes through evolution" (5), and the "only partial change" category (4). An overview of the shares of each category is in figure 4. 
Figure 4: Shares of categories in NO new tools/methods/procedures in controlling

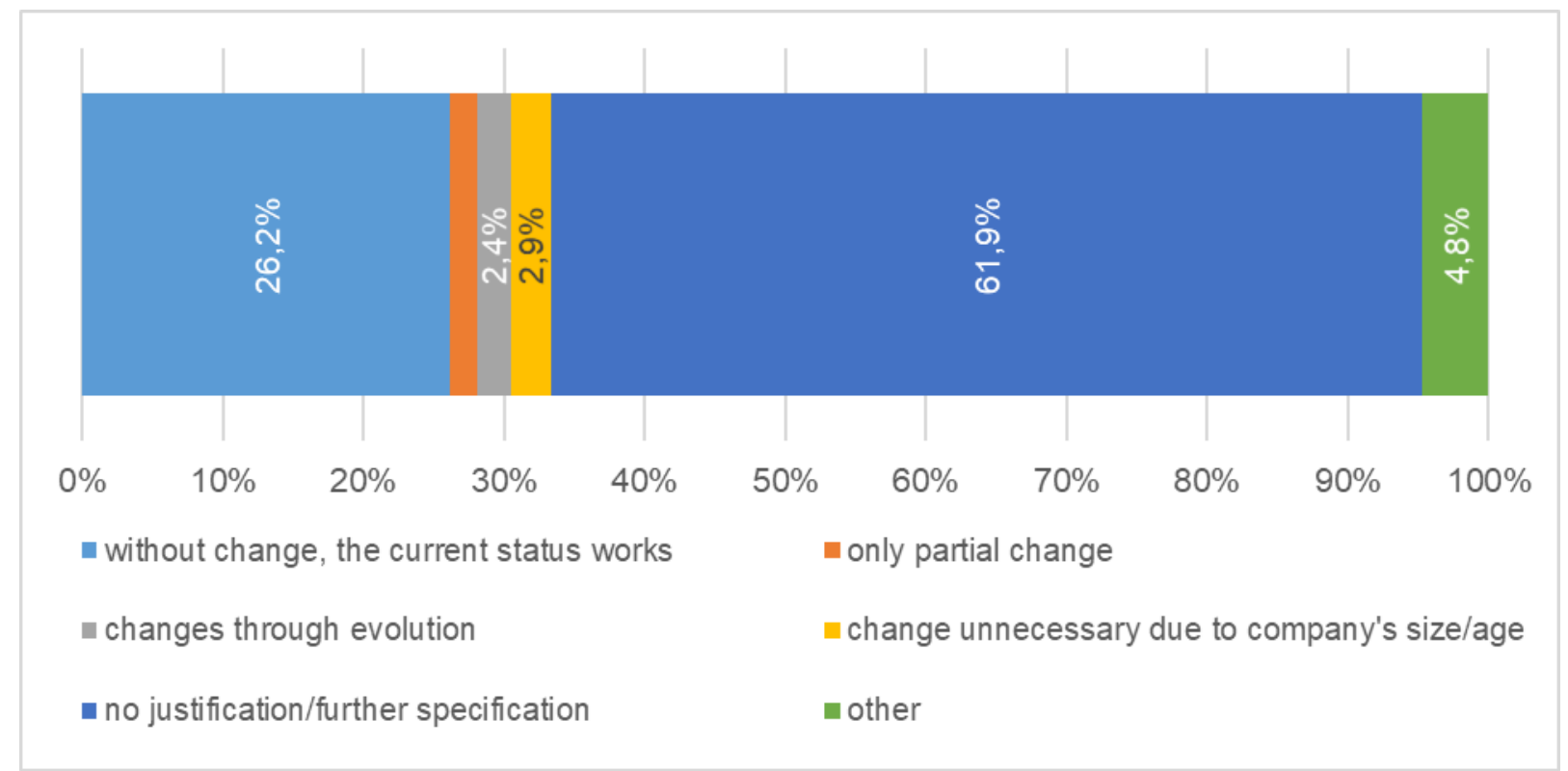

Source: own research results

\subsection{Increasing the intensity of control effort as a subject}

If we want to identify new trends in controlling, an interesting question is whether respondents needed to increase their control efforts towards their subordinates or areas of management they are in charge of.

Up to 230 respondents said they had to increase their control efforts over objects than before. Only eight of those questioned did not justify why it was so. On the other hand, 101 respondents did not have to control more than in the previous period. This results are very interesting, because Slovakia was at that time already in the stage of economic expansion. During such period, controlling efforts should be rather reduced and permitted deviations should be enlarged.

Our results show that managers in medium-large and large enterprises have previously increased the intensity of control. Despite the fact that we have long spotted the underestimation of controlling in micro-enterprises, we have seen a relatively large number of positive responses in this category of enterprises. Regarding the level of management on which the respondent operates, we see that the middle management level had to increase the intensity of their controlling mostly. An interesting fact here is that the share of answers rises with the level of management, but at the highest level of management, we find the lowest share. This result may be due to the inclusion of executives and owners of micro-enterprises among top managers. Based on our results, we can see an interesting relationship. The more important controlling is perceived in the company, the more the controlling intensity increased during the past year. 
In the case of qualitative responses, we find a great deal of diversity, but the common feature of individual justifications seems to be the object of controlling. Simply put, who or what the manager had to control more.

The answer with "who" created the largest category (control of human resources) when we could add up to 70 justifications in here. In the responses to this category, it has often appeared that the expansion of the economy has resulted in the recruitment of new employees. These need more control than those who are longer in employment and therefore the manager had to increase his control efforts.

The second major category that we can associate with controlling objects is control of material sources. Altogether, 53 respondents said they needed, for example, to control more the quality, quantity or price of suppliers of materials and goods.

The "management control" category, with 28 justifications, was generally concerned with the manager's job and its function, which he must perform in supervising the efficient and effective use of the organization's resources.

Into the "other" group (20 justifications), we have included replies that did not fit into specific categories by their very nature. Another important object of controlling was financial resources (15). In some of the justifications, we have discovered that customer payment discipline is getting worse. The "formal control" category (14) includes, in particular, answers such as changes to legislation, health and safety at work, changes in standards or organizational changes, which subsequently led to increased control efforts. The same number of justifications is contained in the "customer demand/marketing" category, which points to the changed requirements and the resulting need for greater control. The category containing justifications about strategy has eight replies and the same number of respondents did not provide any justification. Percentages are shown in Figure 5. 


\section{Figure 5: Shares of categories in increasing the intensity of control effort as a subject}

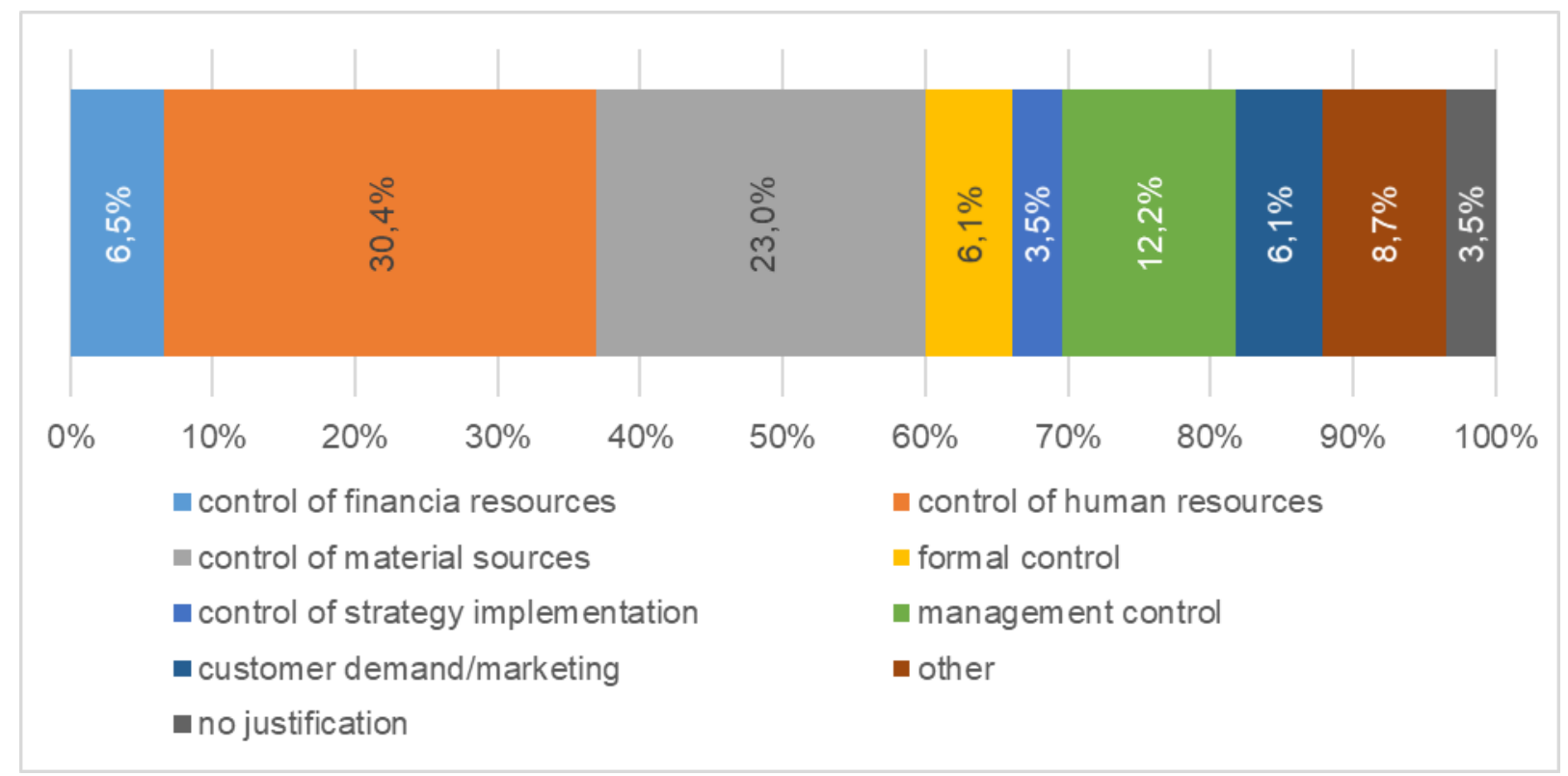

Source: own research results

\subsection{Increased control intensity from another subject}

The last question was strongly linked to our previous research (2014-2015), focused on outer control. It asked if respondents felt increased control intensity from another entity. In the eastern approach to controlling, we can state "in the role of the object of controlling". The exact question in the questionnaire was: "As a manager/entrepreneur who is regularly controlled, have you experienced an increase in the intensity of control from a particular subject over the past year (e.g. senior manager, supervisory board, external audit institution such as the Financial Administration, Slovak Trade Inspection etc.)?"

In the case of this question, negative responses prevailed over the positive ones. A total of 178 respondents did not see an increase in the intensity of controls from a particular subject, 37 of which also justified this answer. In the year, prior to completing the questionnaire 153 respondents were exposed to more intense control. In the last question, we have experienced some fatigue among our respondents, when up to 66 respondents gave a positive response, but did not provide a justification. However, 87 justifications can be considered large enough basis for a qualitative analysis.

The largest category of responses can be created from the justifications specifically naming the subject of outer control. In 28 justifications, for example, tax administration, trade inspection, statistical office, social insurance office and the like appeared.

The second largest category, with fourteen responses, concerned a general increase in the intensity of external control. Either the respondents did not specify specific subjects, 
or they spelled out several of them at once. We have included 14 respondents in the category.

The third category consists of responses that specify why an entity has increased control over the respondent (12 justifications). The same number of justifications (nine) fall into the categories where the specific inner control subject is mentioned and in which it refers to a general increase in the intensity of inner control. Smaller categories are one where respondents are reporting subjects of external and internal control the same time (eight justifications) and a category with other answers (seven justifications). The share of individual categories is shown in Figure 6.

Figure 6: Shares of categories in increased control intensity from another subject

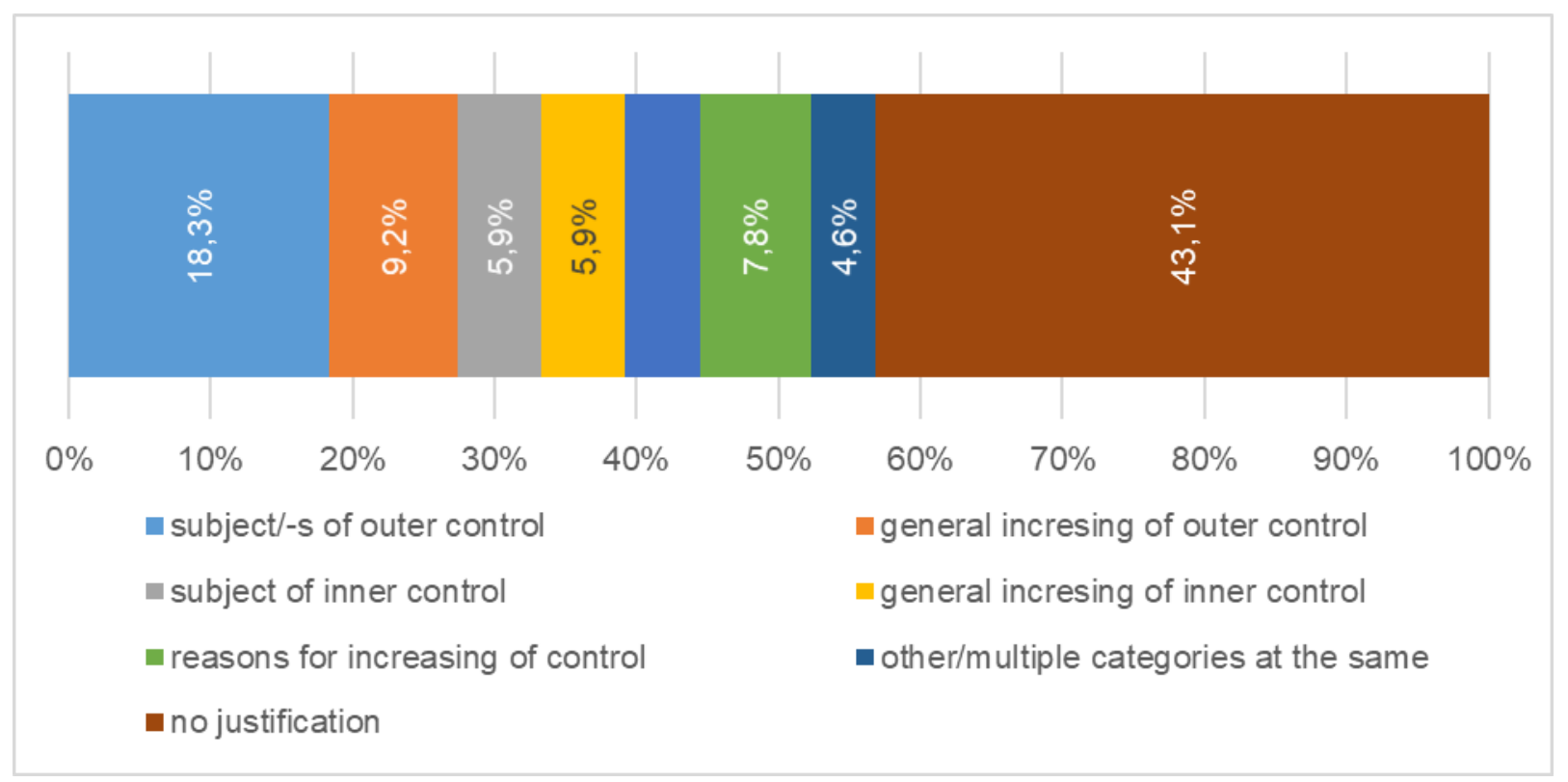

Source: own research results

\section{Conclusions}

The theory of controlling has existed for more than a century, but still has many problems:

- controlling is still the least researched function of management, and in practice many employees and managers consider it very negative;

- the term controlling is also used in the German-written literature and therefore is often associated with controllership;

- the Eastern and Western approach are still far from each other, although they begin to understand the benefits of the other;

- the term of internal control can acquire three meanings, and therefore we would recommend for the Eastern approach to controlling to use the terms inner and outer control. 
Controlling, sometimes referred as the last phase of the management cycle is one of the most important task of managers. While it seemed like it would disappear in the shadow of self-control, it did only hide. As our research shows, managers consider the controlling function to be very significant. Moreover, while it may seem important to managers are only the results, our research speaks in a different way. Many of our respondents have said that not only the goal (result) but also the way to it (the process) is important. Of course, controlling is in its plate to provide the order in business.

Controlling is also closely linked to public administration. Hence, often there are different standards that form the basis for compliance as well as preventive control. It is better to find out the error itself, than to be penalized by the outside body later. On the other hand, internal changes in an organization can also cause to a large extent changes that will then be substantially transformed to changes in controlling. These two reasons were most often mentioned as the impulses of changes in controlling, and a combined share of more than 70 percent of justifications is quite significant.

If something new emerges in controlling, it is according to our findings some innovation or introduction of new control procedures. An important role also play management accounting and (German) controlling, which come with innovative changes. The share of software to help control was relatively low at the turn of 2016 and 2017, but will, according to our estimates, rise significantly in the near future. Automation and digitization of the companies will contribute to this.

Satisfaction with the current status of controlling or the refusal to introduce new tools, methods and procedures in controlling will, in our opinion, only last to the next crisis. However, really good managers are already working on it and controlling them can greatly help to prevent surprises.

To be honest, raised control efforts by managers have surprised us in quantitative results. The Slovak Republic was in the expansion phase at that time, which does not really help controlling. It is precisely on this question that we have greatly appreciated the qualitative answers in the form of justifications. With deeper insights, we have found that the main reason was new employees who require increased supervision at an early stage of their employment. Supplier reliability can also be a significant factor in increasing control effort.

Outer control has a significant impact on the perception of increasing controlling when managers represent a control object. Such a control is much more visible. Inner control can often only be in the form of evaluating statistics or reports, so they do not need to know about the subject. As the biggest reason for these statements, we see the efforts of the local government to improve tax discipline, which also leads to more frequent and more precise tax controls. 


\section{Acknowledgment}

This paper is a part of the research project "Trends of internal control in business entities in the light of new challenges" (no. 1/0135/17) funded by the Scientific Grant Agency VEGA.

\section{References}

Anthony, R.N. (1965). Planning and Control Systems: A Framework for Analysis. Boston: Graduate School of Business Administration.

Atkinson, A.A., Kaplan, R.S., Matsumura, E.M. and Young, S.M. (2012). Management Accounting. Information for Decision-Making and Strategy Execution. Upper Saddle River: Pearson Education.

Committee of Sponsoring Organizations. (2013). Internal Control - Integrated Framework. Executive Summary [Online] Available at: https://na.theiia.org/standardsguidance/topics/Documents/Executive Summary.pdf (Accessed: 5 April 2018).

Eilon, S. (1971). Management Control. Studies in Management. London: Macmillan Education.

Emmanuel, C., Otley, D. and Merchant, K.A. (1990). Accounting for Management Control. Second Edition. London: Springer-Science+Business Media.

Fayol, H. (1949). General and Industrial Management. New York: Pitman Publishing.

Flamholtz, E.G., Das, T.K. and Tsui, A.S. (1985). 'Toward an integrative framework of organizational control.' Accounting, organizations and society. 10(1), 35-50.

Kaufmann, P.J., Welsh, D.H.B., and Bushmarin, N. (1995). 'Locus of Control and Entrepreneurship in the Russian Republic', Entrepreneurship Theory and Practice. 20(1-Fall), p43-56.

Konečný, M. (1998). Management od prvotních řídících dokumentů po současné systémy ř́zení. Karviná: KarTis.

Kráčmar, J. et al. (2013). Kontrolovanie. Bratislava: KARTPRINT.

Merchant, K.A. and Van Der Stede, W.A. (2007). Management Control Systems. Performance Measurement, Evaluation and Incentives. Harlow: Pearson Education.

Merchant, K.A., Van der Stede, W. and Zheng, L. (2003). 'Disciplinary constraints on the advancement of knowledge: the case of organizational incentive systems.' Accounting, Organizations and Society, 28(2), p251-286.

Merchant, K.A. (1982). 'The control function of management.' Sloan management review, 23(4), p43-55.

Petřík, T. (2005). Ekonomické a finanční řízení firmy. Manažerské účetnictví v praxi. Praha: Grada Publishing.

Rotter, J.B. (1954). Social learning and clinical psychology. Englewood Cliffs: Prentice Hall.

Tannenbaum, A.S. (1956). 'The concept of organizational control.' Journal of Social Issues, 12(2), p50-60.

Zhang, X. (2014). Enterprise Management Control Systems in China. Dalian: Springer Science \& Business. 